\title{
Spatial variability of the ten-day rainfall in the months in which the sowing of soybean and winter corn begins in the state of Mato Grosso
}

\section{Variabilidade espacial da precipitação pluviométrica decendial nos meses que iniciam a semeadura da soja e do milho safrinha em Mato Grosso}

\author{
Kássio DE MARCO ${ }^{1}$; Vanessa Rakel Moraes DIAS²; Rivanildo DALLACORT ${ }^{3}$; Elis Dener Lima ALVES ${ }^{4}$; \\ Rafael Cesar TIEPPO5; Dejânia Vieira de ARAÚJO6; João Danilo BARBIERI ${ }^{7}$ \\ ${ }^{1}$ Autor para correspondência; Engenheiro Agrônomo; Universidade do Estado de Mato Grosso - UNEMAT; \\ kassio.marco@hotmail.com \\ 2 Doutoranda em Física Ambiental; Universidade Federal de Mato Grosso - UFMT; vrmdias@hotmail.com \\ ${ }^{3}$ Programa de Pós-graduação em Ambiente e Sistema de Produção Agricola; Universidade do Estado de Mato Grosso - \\ UNEMAT; rivanildo@unemat.br \\ ${ }^{4}$ Doutor em Ciências da Engenharia Ambiental; Universidade de São Paulo - USP; elisdener@hotmail.com \\ ${ }^{5}$ Doutor em Ciências; Universidade de São Paulo - USP; rafaelt@unemat.br \\ ${ }^{6}$ Programa de Pós-graduação em Ambiente e Sistema de Produção Agricola; Universidade do Estado de Mato Grosso - \\ UNEMAT; dejania@unemat.br \\ 7 Mestrando em Ambiente e Sistema de Produção Agrícola; Universidade do Estado de Mato Grosso - UNEMAT; \\ joaodanilobarbieri@hotmail.com
}

Recebido em: 11-02-2014; Aceito em: 05-05-2016

\begin{abstract}
Knowledge of the spatial variability of rainfall in the state of Mato Grosso is very important in decision making, especially in agriculture, aiming at proper planning and optimization of water resources to reduce environmental impacts and increase profitability. The spatial distribution of this variable through geostatistical methods has been highlighted, but it is needed to select the best semivariance model for proper data interpolation. Thus, the objective of this study was to evaluate the spatial and temporal variability of rainfall in the state of Mato Grosso by ordinary kriging, referring to ten-day periods in October and January, a period of great importance for the soybean crop and the cultivation of second crop corn. It was used the 75th percentile of the rainfall of 177 state posts of Mato Grosso and neighboring states. It was observed, through the RE, SDRE and GD values, that the exponential model adjusted better to the semivariograms. Spatial variability was observed in all the analyzed periods of ten days, and the north region of the state is the one which starts the rainy season and that has the highest rainfall rates. The ten-day average rainfall in October did not exceed $20 \mathrm{~mm}$, resulting in the germination and establishment of soybean in the field, and the ten-day average for January was close to $52 \mathrm{~mm}$, which is considered to be harmful to the mechanical harvesting of early maturing soybeans and favorable to the grain filling of the varieties with average and late cycle, being still beneficial to the cultivation of second crop corn.
\end{abstract}

Additional keywords: kriging; main agricultural crops; spatial variability.

\section{Resumo}

O conhecimento da variabilidade espacial da precipitação pluviométrica no Estado de Mato Grosso é muito importante na tomada de decisões, principalmente na área agrícola, visando a um planejamento adequado e otimização dos recursos hídricos para a redução dos impactos ambientais e aumento da rentabilidade. A espacialização desta variável por meio de métodos geoestatísticos tem-se destacado, porém é necessário selecionar o melhor modelo de semivariância para uma adequada interpolação dos dados. Assim, o objetivo deste trabalho foi avaliar a variabilidade espaçotemporal da precipitação pluvial no Estado de Mato Grosso por krigagem ordinária, referente aos decêndios dos meses de outubro e janeiro, período de grande importância para a cultura da soja e para o cultivo do milho segunda safra. Utilizou-se o percentil $75 \%$ da precipitação pluvial de 177 postos do Estado de Mato Grosso e Estados vizinhos. Observou-se, por meio dos valores de ER, $S_{E R}$ e $G D$, que 0 modelo exponencial se ajustou melhor aos semivariogramas. Foi constatada variabilidade espacial em todos os decêndios analisados, sendo que a região ao norte do Estado é a que inicia o período das chuvas e que apresenta os maiores índices de precipitação. A média decendial de precipitação de outubro não ultrapassou $20 \mathrm{~mm}$, implicando a germinação e o estabelecimento da soja no campo, e a média decendial para janeiro encontrou-se próxima aos $52 \mathrm{~mm}$, prejudicial à colheita mecanizada da soja ciclo precoce e favorável ao enchimento de grãos das variedades dos ciclos médio e tardio, benéfico ainda ao cultivo do milho segunda safra.

Palavras-chave adicionais: krigagem; principais culturas agrícolas; variabilidade espacial. 


\section{Introduction}

The state of Mato Grosso, located in the Midwest region of Brazil, is represented by the Pantanal, Cerrado and Amazon Forest biomes, being the third largest state of Brazil. It has physical peculiarities such as vegetation, topography and soils, in addition to the geographical location, which directly influence the rainfall distribution.

Farming is considered the main source of income and development of the state, covering 48 million hectares of fertile and highly productive agricultural lands (IBGE, 2012), this activity being strongly influenced by climate conditions, in particular the rainfall distribution, since it is the most economical and environmentally friendly activity of water use (Vieira et al., 2010). The state is established as the largest national producer of soybean and second crop corn (CONAB, 2012).

This state can be divided into two seasons: dry season, from May to September, and rainy season, from October to April, effect evidenced by Dallacort et al. (2010) and Casarin et al. (2008) in a study on regions of the state of Mato Grosso, which according to Assad et al. (1993) can be, in general, widespread throughout the Midwest region of Brazil.

Rainfall is the climatic element that has the greatest influence on environmental conditions, changing the water balance and, indirectly, the temperature of the air, soil and the relative air humidity, essential elements for the growth and development of plants (Carvalho \& Assad, 2005). The rainfall distribution in a region determines the predominant type of farm (Buriol et al., 2007), since it is a limiting factor for production, and can decrease productivity or even make the cultivation impossible.

The distribution and regularity of rainfall is extremely important to get a good grain production, being determinant mainly for the production of second crop corn, as this is directly influenced by the onset of the rains, which takes place in October (period when the soybean is sown). The ideal time for planting corn being from late January to the first half of March; if the planting takes place outside this period, it is considered at risk due to water scarcity (CONAB, 2012).

This period coincides with the soybean harvest, which is favored by low rainfall, so that the relative humidity of grains at harvest is within the ideal range, between 13 and 15\% (Embrapa, 2005), thus providing greater grain production and quality. Pinheiro Neto \& Gamero (2001), evaluating quantitative losses in the soybean harvest, observed that the harvest performed with humidity less than 12.5\% resulted in higher losses. Costa \& Tavares (1995) and Mesquita et al. (1993) found lower crop losses when this was performed with humidity levels between $11.5 \%$ and $14.5 \%$.

Nonetheless, the lack of rainfall, which is favorable to the soybean crop, can be detrimental to establishing uniform stands of winter corn, since sowing should be performed soon after the soybean harvest to prevent water deficit in the subsequent stages (CONAB, 2012).

In the crop establishment period, it is required a large volume of water for the seed to start its soaking process and stimulate the biochemical reactions that result in the formation of seedlings (Taiz \& Zeiger, 2004), which is one of the most important factors that influence germination (Khajeh-Hosseini et al., 2003).

Using the estimate of precipitation with a certain level of probability becomes important for the agricultural planning, with regard to the best time for tillage, harvesting, sowing, crop production, application of fertilizers and pesticides, water management, among others (Ávila et al., 2009; Carvalho \& Assad, 2005). The probability of precipitation means a minimum value of rainfall that can occur in a season at a specific probability, taking into account that for agriculture purposes the level of $75 \%$ is used (Bernardo et al., 2006).

Despite the fact that the state of Mato Grosso has an extensive land area, it has a not very dense population of weather stations, being fundamental the use of interpolation methods for the spatial distribution of climate variables. Among the spatial interpolation methods for generating maps, kriging is highlighted, for being a geostatistical method (Viola et al., 2010; Alves \& Vecchia, 2011).

Kriging has, in principle, the theory of regionalized variables, i.e., it starts from the assumption that the values of close samples tend to be similar and the values of distant samples tend to be more discrepant, considering the spatial variation of a given statistically homogeneous variable in one area, the spatial variation being quantified by an experimental semivariogram (Marcuzzo et al., 2011).

Thus, the objective of this study was to check the spatial and temporal variability of rainfall in the state of Mato Grosso by ordinary kriging, referring to ten-day periods in October and January, a very important period for the soybean crop and the cultivation of second crop corn.

\section{Material and methods}

The work was developed in the Agrometeorology Laboratory of the Center for Research and Agro-Environmental Development (CPEDA) of the State University of Mato Grosso - UNEMAT, located in the city of Tangará da Serra (MT), with the geographical coordinates $14^{\circ} 39^{\prime} \mathrm{S}$ and $57^{\circ} 25^{\prime} \mathrm{W}$, and an average altitude of 440 meters.

To evaluate the spatial distribution of the 75th percentile of rainfall in the ten-day periods of the months of October and January, data from 177 weather stations in the state of Mato Grosso and neighboring states were used. Rainfall records were obtained on the website of the National Water Agency-ANA (Hidroweb, 2008), with historical series of at least ten years of daily rainfall data. 
According to Gomes \& Cruz (2002), the 75th percentile is justified by the increase in the degree of reliability in the event of rainfall, being suitable for agricultural planning. The ten-day periods of October and January were analyzed for being periods of great importance for the soybean crop (Gomes \& Cruz, 2002) and the sowing of the second crop corn.

In October, the beginning of the soybean sowing takes place, and in January begins the harvest of early maturing varieties, a period that coincides with the sowing of the second crop corn, which can be carried out until the second ten days of February; if the planting takes place outside this period, it is considered extremely risky (CONAB, 2012).

The spatial variability was analyzed through the classical estimator of Matheron (Burrough \& Mcdonnell, 1998). Theoretical models were adjusted to the experimental semivariogram generated, providing the parameters ' $C_{0}$ ' (nugget effect), ' $C_{0}+C_{1}$ ' (sill) and ' $a$ ' (range). The spherical, exponential and Gaussian models (Burrough \& Mcdonnell, 1998) were adjusted. The experimental semivariograms were generated using resources offered by the $\mathrm{R}$ software version 2.12.2 and the GeoR extension. The cross-validation technique was used as a comparison criterion to evaluate the three models adjusted to the experimental semivariograms. This technique consists in estimating, based on the adjusted semivariogram model, the sampled points, allowing thus to compare the estimated value to the real one, by working with the mean reduced error $(\overline{R E})$ and the standard deviation of reduced errors (SDRE); in this sense, the best model is one that has $(\overline{R E})$ close to zero and SDRE close to one (Mello, 2004).

Subsequently, it was calculated the degree of spatial dependence $(G D)$, evaluated, according to Mello (2004), by the ratio between the nugget effect $\left(C_{0}\right)$ and the sill $\left(C_{0}+C_{1}\right)$, which has the following classification: $\leq 25 \%$ (weak), between 25 and $75 \%$ (moderate) and $\geq 75 \%$ (strong).

Once the best model is selected, it was proceeded to build maps using kriging as interpolation method. R program was used, in addition to the geostatistical analysis package geoR (Ribeiro Junior \& Diggle, 2001).

\section{Results and discussions}

\section{General descriptive analysis}

The average rainfall values are above $12 \mathrm{~mm}$ for all ten-day periods, being observed an increasing variation in the average ten-day rainfall in October. In January, there was a regularity in the rainfall distribution, with ten-day average around $50 \mathrm{~mm}$ (Table 1). According to Sousa (1998) and Assad et al. (1993), the Cerrado region has a transitional period of increasing rainfall in the spring season (September, October and November), with a gradual increase in rainfall in late spring, coinciding with the onset of summer in the month of December.

Table 1 - Descriptive statistics for the 75th percentile of the ten-day rainfall $(\mathrm{mm})$ for the months of October and January, obtained in 177 rainfall stations in the state of Mato Grosso.

\begin{tabular}{ccccccc}
\hline Ten-days & Minimum & Median & Average & Maximum & Kurtosis $\left(C_{k}\right)$ & Asymmetry \\
\hline Oct_1 & 0.0 & 11.3 & 12.29 & 49.4 & 3.98 & 1.37 \\
Oct_2 & 0.0 & 15.7 & 16.81 & 41.7 & -0.04 & 0.51 \\
Oct_3 & 4.8 & 25.7 & 26.77 & 57.2 & 0.67 & 0.68 \\
Jan_1 & 19.4 & 56.9 & 57.45 & 108 & -0.11 & 0.16 \\
Jan_2 & 8.8 & 45.4 & 48.63 & 105.7 & -0.08 & 0.53 \\
Jan_3 & 24.1 & 47.1 & 50.01 & 101.2 & 0.45 & 0.69 \\
\hline
\end{tabular}

The lowest average precipitation occurred in the first ten days of October, with an average below $13 \mathrm{~mm}$, while the highest value was observed in the first ten days of January $(57.45 \mathrm{~mm})$. When comparing the average with the median, there is a low variation between the rainfall values, which makes them close to the normality, a fact also evidenced by the value of the asymmetry coefficient (close to 0 ), this being a good parameter for the ten-day evaluation of the rainfall for the state of Mato Grosso; notwithstanding, when the maximum and minimum values of monthly precipitation were compared, a wide variation was found between the values.

The kurtosis coefficient determines the degree of flattening of a distribution in relation to a standard distribution, called normal curve (Mousinho et al., 2006). The kurtosis coefficient $\left(C_{k}\right)$ values near 0 for the second ten days of October $(-0.04)$, first ten days of January $(-0.11)$ and second ten days of January $(-0.08)$ show a platykurtic distribution, but close to the normality $\left(C_{k}=0\right.$, mesokurtic), which also happens for the leptokurtic distribution, where the kurtosis coefficient values were $3.98,0.67$ and 0.45 for the first ten days of October, third ten days of October and third ten days of January, respectively.

\section{Semivariogram analysis}

The spatial dependence of the 75th percentile of rainfall in the ten-day periods of October and January in the state of Mato Grosso was found through isotropic variogram models. Table 2 shows the values of the parameters nugget effect $\left(\mathrm{C}_{0}\right)$, sill $\left(\mathrm{C}_{0}+\mathrm{C}_{1}\right)$, range $(\mathrm{a})$, mean reduced error $(\overline{R E})$, standard deviation of reduced errors (SDRE) obtained by cross-validation, and degree of spatial dependence (GD). 
Table 2 - Parameters of the semivariogram models, mean reduced error $(\overline{R E})$, standard deviation of reduced errors (SDRE) and spatial dependence (GD).

\begin{tabular}{|c|c|c|c|c|c|c|c|c|}
\hline Month & Ten-days & Model & $\mathrm{CO}$ & $\mathrm{C} 0+\mathrm{C} 1$ & $\mathrm{a}(\mathrm{m})$ & $\overline{R E}$ & SDRE & GD (\%) \\
\hline \multirow{9}{*}{ October } & \multirow{3}{*}{ 1st } & spherical & 18.47 & 53.56 & 1089400 & -0.00 & 1.09 & 74 \\
\hline & & exponential ${ }^{*}$ & 19.35 & 87.49 & 1090000 & -0.00 & 1.06 & 82 \\
\hline & & Gaussian & 25.22 & 47.63 & 542187 & -0.00 & 1.14 & 65 \\
\hline & \multirow{3}{*}{ 2nd } & spherical & 26.64 & 57.67 & 1080000 & -0.00 & 1.07 & 68 \\
\hline & & exponential* & 26.36 & 98.54 & 1080000 & -0.00 & 1.06 & 79 \\
\hline & & Gaussian & 32.00 & 58.03 & 602927 & 0.00 & 1.11 & 64 \\
\hline & \multirow{3}{*}{$3 \mathrm{rd}$} & spherical & 34.78 & 88.96 & 931723 & -0.00 & 1.05 & 72 \\
\hline & & exponential* & 36.06 & 145.58 & 930000 & -0.00 & 1.03 & 80 \\
\hline & & Gaussian & 40.00 & 85.70 & 455968 & -0.00 & 1.15 & 68 \\
\hline \multirow{9}{*}{ January } & \multirow{3}{*}{ 1st } & Spherical & 91.38 & 257.36 & 902893 & -0.00 & 1.03 & 74 \\
\hline & & exponential $^{*}$ & 99.99 & 436.24 & 990000 & -0.00 & 1.00 & 81 \\
\hline & & Gaussian & 125.85 & 229.64 & 461776 & -0.00 & 1.04 & 65 \\
\hline & \multirow{3}{*}{ 2nd } & spherical & 73.71 & 88.29 & 451080 & 0.00 & 1.01 & 54 \\
\hline & & exponential* & 78.00 & 102.60 & 280573 & -0.00 & 0.97 & 57 \\
\hline & & Gaussian & 78.00 & 80.59 & 181867 & 0.00 & 1.06 & 51 \\
\hline & \multirow{3}{*}{3 rd } & spherical & 66.60 & 67.84 & 362750 & -0.00 & 1.11 & 50 \\
\hline & & exponential* & 62.46 & 78.08 & 159069 & -0.00 & 1.06 & 56 \\
\hline & & Gaussian & 68.00 & 62.76 & 128721 & 0.00 & 1.12 & 48 \\
\hline
\end{tabular}

The results of the values of mean reduced errors $(\overline{R E})$ and standard deviation of the mean reduced errors (SDRE) were accurate and precise, with values close to zero and one, respectively, showing similarity between the models analyzed, on that basis, the decisive criterion to choose the best model to be used in kriging was the greatest degree of spatial dependence.

In all cases, the exponential model adjusted better to the experimental semivariograms (Figure 1), in agreement with the results obtained in other rainfall distribution studies, such as that for Minas Gerais, in which the semivariograms were adjusted by spherical, exponential and Gaussian models, the exponential model being superior to the others in $75 \%$ of the cases analyzed (Mello et al., 2008). This was also found in a study of the average annual rainfall for the state of São Paulo, where the exponential model allowed a better adjustment of semivariograms (Carvalho et al., 2004).

The degree of spatial dependence (GD) for the exponential model is considered strong for the month of October and for the first ten days of January $(\geq 75 \%)$. Yet for the spherical and Gaussian models, the GD value shows a moderate spatial dependence in all analyzed periods of ten days (between 25 and $75 \%$ ) (Mello et al., 2003) (Table 2).

The largest values of sill $\left(\mathrm{C}_{0}+\mathrm{C}_{1}\right)$ were observed for the exponential model in all analyzed periods of ten days. Furthermore, the values of the nugget effect $\left(\mathrm{C}_{0}\right)$ were close to the values of the other models, indicating this as the best model (Table 2).

In October, especially in the second and third ten-day periods (Figure 2), there was a wide variation in rainfall rates throughout the state, which can endanger the germination of soybean, since it needs to absorb $50 \%$ of its weight in water in the phases of sowing/emergence (Farias et al., 2001). At this stage, the water content in the soil should not exceed $85 \%$ of the maximum total available water, nor be less than $50 \%$ (Moraes et al., 2004).

In general, the north region of the state had the highest rainfall rates in the three ten-day periods of October (Figure 2). Taking into account the distribution and regularity of rainfall in this locality, the soybean germination can begin in the first ten days of October, yet this month is characterized by low rainfall $(56 \mathrm{~mm})$, with ten-day average around $18.6 \mathrm{~mm}$, which could affect the soybean sowing in other regions of the state. The north region of the state also has high rainfall rates in January (156 mm), with ten-day average around 52 $\mathrm{mm}$, which can be harmful to the mechanical harvesting of early maturing soybeans.

The sowing of soybean in October is favorable for the cultivation of second crop corn, since, taking into account the average soybean cycle, of 120 days, the sowing can be performed at the beginning of February, minimizing the risk of water deficit (CONAB, 2012). Another determining factor in the advance of sowing is to prevent and/or delay the most severe damage caused by rust. The tendency is to start the sowing as soon as possible to ensure high yields (Garcia et al., 2007).

The maps for the first and second ten days of January showed less variation in the rainfall rates, with lower values in the southern region of the state, favoring the harvest of early maturing soybeans, this period also being the most appropriate for the reproductive stage (flowering to grain filling) of the soybean of average and late maturity, the regions located further south being more needy of attention (Garcia et al., 2007). 



Figure 1 - Spherical, exponential and Gaussian models adjusted to the experimental semivariograms for the 1st (a), 2nd (b) and 3rd (c) ten days of October and 1st (d), 2nd (e) and 3rd (f) ten days of January. 

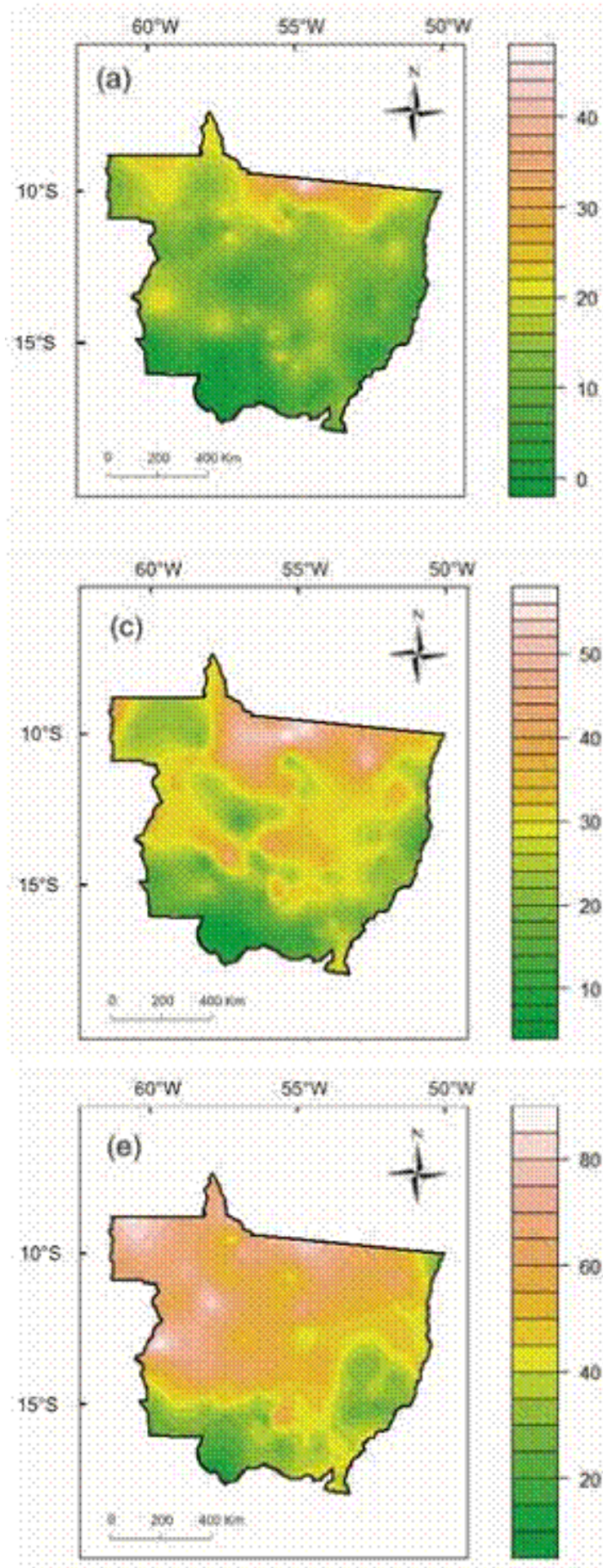
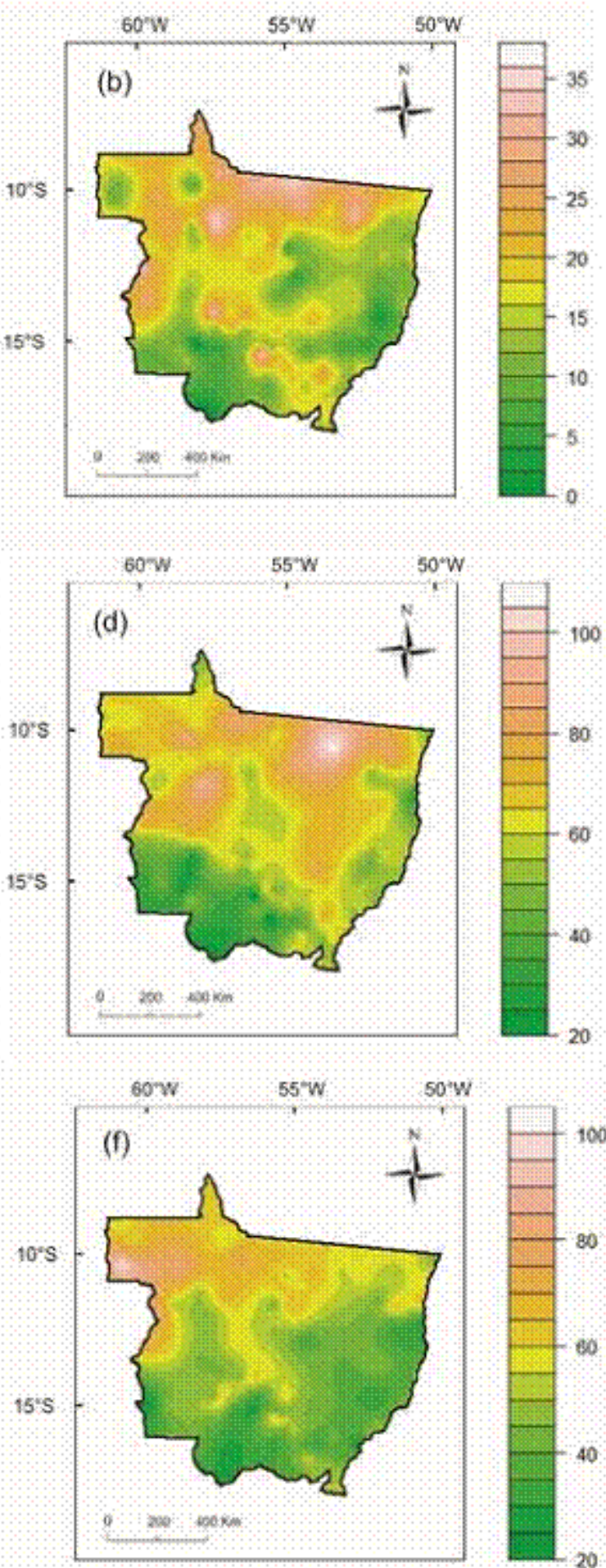

Figure 2 - Maps of the spatial variability of rainfall in the state of Mato Grosso for the 1st (a), 2nd (b) and 3rd (c) ten days of October and 1st (d), 2nd (e) and 3rd (f) ten days of January.

This period is considered the most critical in view of the water requirement by soybeans for high grain yield, the rainfall in this period being the most determining factor in defining areas suitable for soybean cultivation (Farias et al., 2001).

Overall, it was found that the rainfall did not exceed $30 \mathrm{~mm}$; in the ten-day periods of October, greater rainfall rates are observed in the northern region of the state, but it is possible to identify an uneven distribution, with some areas of high rainfall rates in the central region of the state, a factor that should be taken into account in the soybean sowing.

The month of January has an average tenday rainfall above $48 \mathrm{~mm}$, which can be harmful to 
the mechanical harvesting of soybeans; notwithstanding, it favors the cultivation of the second crop corn and of the soybean with average and late cycle, as this will be in the grain-filling stage.

\section{Conclusions}

The rainfall in Mato Grosso presented a spatial dependence structure for the ten-day periods of October and January and the best adjustment model was the exponential.

The anticipation of soybean sowing for the first ten days of October and the use of early maturing cultivars are strategies to minimize the pressure by rust in the culture and reduce the risk of water deficit in the second crop corn.

The average ten-day rainfall in October was $18.6 \mathrm{~mm}$, resulting in the germination and establishment of soybean in the field, especially in the first ten days. However, for the month of January, the high value of the ten-day average (close to $52 \mathrm{~mm}$ ) can be harmful to the mechanical harvesting of early maturing soybeans and favorable to the grain filling of the varieties of average and late cycle, and still beneficial to the cultivation of second crop corn.

\section{Acknowledgments}

We thank the National Council for Scientific and Technological Development - CNPq, for granting the Scientific Initiation scholarship to the first author; and the National Agency of Water - ANA, for providing the rainfall data.

\section{References}

Alves EDL, Vecchia FAS (2011) Análise de diferentes métodos de interpolação para a precipitação pluvial no Estado de Goiás. Acta Scientiarum. Human and Social Sciences 33(2):193-197.

Assad ED, Sano EE, Masutomo R, Castro LHR, Silva FAM (1993) Veranicos na região dos cerrados brasileiros: freqüências e probabilidades de ocorrência. Pesquisa Agropecuária Brasileira 28(9):993-1003.

Ávila LF, Mello CR, Viola MR (2009) Mapeamento da precipitação mínima provável para o sul de Minas Gerais. Revista Brasileira de Engenharia Agrícola e Ambiental 13(6):906-915.

Bernardo S, Soares AA, Mantovani EC (2006) Manual de irrigação. Viçosa: Imprensa Universitária. 378p.

Buriol GA, Estefanel V, Chagas AC, Eberhardt D (2007) Clima e vegetação natural do Estado do Rio Grande do Sul segundo o diagrama climático de Walter e Lieth. Ciência Florestal 17(2):91-100.

Burrough PA, Mcdonnell RA (1998) Principles of geographical information systems. Oxford: Oxford University Press, 674p.
Carvalho JRP, Assad ED (2005) Análise espacial da precipitação pluviométrica no Estado de São Paulo: comparação de métodos de interpolação. Engenharia Agrícola 25(2):377-384.

Carvalho JRP, Vieira SR, Vendrusculo LG (2004) Uso da técnica de mínimos quadrados ponderados para ajuste de modelos aos semivariogramas. Campinas: Embrapa Informática Agropecuária, (Boletim de Pesquisa e Desenvolvimento 11).

Casarin R, Silva Neves SMA, Neves RJ (2008) Uso da terra e qualidade da água da Bacia hidrográfica Paraguai/Jauquara. Revista Geográfica Acadêmica 2(1): 33-42.

CONAB - Companhia Nacional De Abastecimento (2012) Acompanhamento. Safra Brasileira de Grãos 2011/12, Oitavo Levantamento - Maio/2012. Available at $<$ http://www.conab.gov.br/OlalaCMS/uploads/arquivos/ 12_05_10_08_49_52_boletim_maio_2012.pdf>. (Accessed nov 29 2012).

Costa NP, Tavares LCV (1995) Fatores responsáveis pelos elevados percentuais de perdas de grãos durante a colheita mecânica em soja. Informativo Abrates 5(1):17-25.

Dallacort R, Moreira PSP, Inoue $\mathrm{MH}$, Silva DS, Carvalho IF, Santos C (2010) Wind speed and direction characterision in Tangará da Serra, Mato Grosso state, Brazil. Revista Brasileira de Meteorologia 25(3):359-364.

Embrapa - Empresa Brasileira De Pesquisa Agropecuária (2005) Tecnologias de produção de soja. Londrina: Embrapa Soja, 2005.

Farias JRB, Assad ED, Almeida LR, Evangelista BA, Lazzarotto C, Neurnaier N, Nepornuceno AL (2001) Caracterização de risco de déficit hídrico nas regiões produtoras de soja no Brasil. Revista Brasileira de Agrometeorologia 9(3):415-421.

Garcia A, Pípolo AE, Lopes ION, Portugal FAF (2007) Instalação da lavoura de soja: época, cultivares, espaçamento e popuação de plantas. Londrina: EMBRAPA Soja (Circular Técnica 51).

Gomes BM, Cruz RL (2002) Comportamento espacial dos percentis 75 da precipitação decendial para 0 Estado de São Paulo, na primavera. Irriga 7(2):142153.

IBGE - Instituto Brasileiro de Geografia e Estatística (2012) Estatística da Produção Agrícola, Março de 2012. Rio de Janeiro: IBGE, 2012. Available in <http://www.ibge.gov.br/home/estatistica/indicadores/a gropecuaria/lspa/estProdAgr_201203.pdf>. (Accessed at 2012). 
Khajeh-Hosseini M, Powell AA, Bingham IJ (2003) The interaction between salinity stress and seed vigour during germination of soybean seeds. Seed Science and Technology 31(3):715-725.

Marcuzzo FFN, Andrade LR, Melo DCR (2011) Métodos de interpolação matemática no mapeamento de chuvas do estado do Mato Grosso. Revista Brasileira de Geografia Física 4(1):793-804.

Mello JM (2004) Geoestatística aplicada ao inventário florestal. - Escola Superior de Agricultura Luiz de Queiroz (Tese de Doutorado em Recursos Florestais).

Mello CR, Lima JM, Silva AM, Mello JM, Oliveira MS (2003) Krigagem e inverso do quadrado da distância para interpolação dos parâmetros da equação de chuvas intensas. Revista Brasileira de Ciência do Solo 27(5):925-933.

Mello CR, Viola MR, Mello JM, Silva AM (2008) Continuidade espacial de chuvas intensas no estado de Minas Gerais. Ciência e Agrotecnologia 32(2):532-539.

Mesquita CM, Tavares LCV, Costa NP, Galerani PR, Andrade JGM, Domit LA (1993) Diagnóstico de desperdício na colheita de soja na safra 1992/93. Informativo Abrates, 3(3):52.

Moraes JCC, Peixoto CP, Santos JMB, Brandelero E, Peixoto MFSP, Silva V (2004) Caracterização de dez cultivares de soja nas condições agroecológicas do Recôncavo Baiano. Magistra 16(3):33-41.
Mousinho FEP, Júnior ASA, Gonçalves ACA, Frizzone JA (2006) Variabilidade espacial dos percentis 75 da precipitação pluvial anual para o Estado do Piauí. Irriga 11(2):178-187.

Pinheiro Neto R, Gamero CA (2001) Avaliação das perdas quantitativas de grãos na colheita de soja. In: CONGRESSO BRASILEIRO DE ENGENHARIA AGRÍCOLA 25. Paraná, Anais..., p.13-16.

Ribeiro Junior PJ, Diggle PJ (2001) GeoR: A package for geostatistical analysis. R-News 1(2):15-18.

Hidroweb - Sistema de informações hidrológicas (2008). Available at <http://hidroweb.ana.gov.br/>. (Accessed jun 18 2008).

Sousa SAV(1998) Programa computacional para simulação da ocorrência de veranicos e queda de rendimento. Pesquisa Agropecuária Brasileira 33(12):1952-1956.

Taiz L, Zeiger E (2004) Fisiologia vegetal. Porto Alegre: ARTMED. 843p.

Vieira JPG, Souza MJH, Teixeira JM, Carvalho FP (2010) Estudo da precipitação mensal durante a estação chuvosa em Diamantina, Minas Gerais. Revista Brasileira de Engenharia Agrícola e Ambiental 14(7):762-767.

Viola MR, Mello CR, Pinto DBF, Mello JM, Ávila LF (2010) Métodos de interpolação espacial para o mapeamento da precipitação pluvial. Revista Brasileira de Engenharia Agrícola e Ambiental 14(9):970-978. 